\title{
PRIORITIZING POSITIVITY SCALE: PSYCHOMETRIC PROPERTIES OF THE POLISH ADAPTATION (PPS-PL)
}

\author{
Jaśmina Machlah and Mariusz Zięba \\ SWPS University of Social Sciences and Humanities \\ Institute of Psychology, Poznań
}

\begin{abstract}
Prioritizing positivity means making decisions and choices about everyday activities to increase the chances of experiencing positive emotions. People have different levels of prioritizing positivity (PP), and the Prioritizing Positivity Scale is used to capture such individual differences. Past research indicates that prioritizing positivity is conducive to well-being. The following article presents the Polish adaptation of the Prioritizing Positivity Scale (PPS) and its psychometric properties. There were three samples in this study $\left(n_{1}=229, n_{2}=253, n_{3}=226\right)$. The method has a single-factor structure and high internal consistency (Cronbach's $\alpha=.84$ to .87 ). Prioritizing positivity measured with the Polish version of the Prioritizing Positivity Scale was associated with several indicators of well-being.
\end{abstract}

Keywords: prioritizing positivity; psychometric properties; well-being; satisfaction with life; happiness.

JAŚMINA MaChlaH, https://orcid.org/0000-0003-4524-5012; MaRIUSZ ZiĘBA, https://orcid. org/0000-0002-3492-2236. Correspondence concerning this article can be addressed to JAŚMINA MaCHLAH, SWPS Uniwersytet Humanistycznospołeczny, Instytut Psychologii, ul. Kutrzeby 10, 61-719 Poznań, Poland; e-mail: jmachlah@swps.edu.pl.

We are very grateful to Lahnna Catalino for her helpful comments on the initial version of the paper.

Handling editor: Piotr Oleś, John Paul II Catholic University of Lublin.

Received 14 Oct. 2020. Received in revised form 18 Aug. 2021. Accepted 14 Sept. 2021. Published online 5 Nov. 2021. 


\section{Prioritizing Positivity Scale: \\ Psychometric Properties of the Polish Adaptation (PPS-PL)}

Seeking happiness seems to be an inherent quality for most people, but whether we achieve the happiness state depends on the methods used to pursue it. Recent research shows that seeking pleasant states in daily life activities is conducive to attaining psychological well-being and happiness in broader terms (Catalino et al., 2014). The broaden-and-build theory (Fredrickson, 2001) posits that particular discrete positive emotions (i.e., joy, interest, contentment, pride, and love) broaden human momentary thought-action repertoires and help to build long-lasting, personal resources (physical, psychological, intellectual, social). In addition, the experience of these pleasant states is related to greater subjective satisfaction with life (Cohn et al., 2009; Diener et al., 1985; Diener et al., 1991; Schütz et al., 2013), which is one of the facets of happiness and represents perceptions of health and psychological well-being.

\section{Prioritizing Positivity}

Pursuing happiness by seeking pleasant states in how we structure our day might be a good way to build and broaden subjective happiness. Such pursuit of happiness is called prioritizing positivity (PP). A personality difference which reflects the ability to effectively look for pleasant states in everyday activities (Catalino et al., 2014). That same research shows that individuals who prioritize positivity experience positive emotions more frequently than individuals who do not. Many studies report a positive correlation between prioritizing positivity and well-being (Catalino et al., 2014; Catalino et al., 2020; Datu \& King, 2016; Littmann-Ovadia \& Russo-Netzer, 2019; Passmore et al., 2018; Russo-Netzer, 2019). In addition, prioritizing positivity is linked with higher overall levels of life satisfaction and less depressive symptomatology, more personal resources such as positive relations with others, ego-resilience, self-compassion, and mindfulness (Catalino et al., 2014). The latest research demonstrates that prioritizing positivity is positively correlated with sensitivity to pleasant events, various positive psychological traits, extraversion, conscientiousness, self-control, agreeableness, and openness to experience. Moreover, it is also negatively correlated with neuroticism and negative aspects of psychological well-being (Catalino \& Boulton, 2020). 


\section{The Measurement of Prioritizing Positivity}

The Prioritizing Positivity Scale (PPS) measures the tendency to use pleasant states as a criterion for structuring daily life. Catalino and colleagues (2014) first used it in a preliminary online study. Their participants indicated agreement or disagreement on a 9-point scale (from 1 = strongly disagree to $9=$ strongly agree) with seven prioritizing positivity items. However, after conducting further analyses, the scale authors removed two items as one caused problems for model estimation (Catalino et al., 2014), and the other did not conceptually fit with the other five items (Catalino \& Boulton, 2020).

The preliminary research, as well as other studies which used a 6-item scale, report Cronbach's alpha ranging from .74 to .85 (Catalino et al., 2014; Datu \& King, 2016; Littman-Ovadia \& Russo-Netzer, 2019; Passmore et al., 2018; Russo-Netzer, 2019). The latest research tested the reliability of the revised 5-item version of the scale using the omega total coefficient. In each sample, the reliability was acceptable and ranged from .79 to .82 . In the same research, coefficients testing discriminant validity ranged from .09 to .20 (Catalino \& Boulton, 2020).

The purpose of this study is to provide a Polish adaptation of the 5-item version of the PPS and to test its psychometric properties. It was first developed and then revised by Catalino and colleagues $(2014,2020)$. We conducted the study to examine the structure of the PPS as well the relationship of PP with personality traits, indicators of subjective well-being and other psychosocial resources, which served to verify the external validity of PP further.

\section{METHOD}

\section{Participants}

Our research consisted of three separate studies. Study 1 was conducted on a sample of 229 people (195 women) aged $18-51$ years $(M=25.33 ; S D=7.41)$. The participants completed three questionnaires measuring prioritizing positivity, positive orientation, and the BigFive traits of personality. The sample consisted of 253 people (196 women), aged $17-76$ years $(M=29.91, S D=10.21)$. In Study 2 the participants filled out questionnaires measuring prioritizing positivity, positive and negative emotions, satisfaction with life, depression and illness symptoms, ego-resilience, self-compassion, mindfulness, and positive relations with others. The last group of participants in Sample 3 consisted of 226 people (139 women), 
aged $17-71$ years $(M=34.45, S D=12.57)$. The participants filled out scales measuring prioritizing positivity, positive and negative emotions, satisfaction with life, depression symptoms, subjective happiness, and valuing happiness.

\section{Procedure}

The study took place online. The participants were recruited via emails, university-wide emails, and social networking sites (e.g., Facebook). Some of the participants who were students at our university received credit points for participation.

\section{Measurement}

\section{Prioritizing Positivity Scale-PL}

To develop a Polish language version, English and Polish-speaking psychologists prepared three separate English-Polish translation versions of the PPS. Next, we compared all three versions of the scale and created a final Polish version. Then, an accredited Polish-English translator checked the accuracy of the Polish translation using the back-to-back translation method. Finally, we consulted the final version of the back-to-back translation with L. Catalino.

The scale measures the tendency to use pleasant states as a criterion for structuring daily life. The PPS consists of five statements rated on a 9-point Likert scale ranging from 1 (strongly disagree) to 9 (strongly agree).

\section{Positivity Scale}

The Positivity Scale (Caprara et al., 2012) measures Positive orientation, which is the basic tendency to notice and attach importance to the positive aspects of life, experiences, and oneself, which combines three components: self-esteem, optimism, and satisfaction with life (Caprara, 2009). The Polish adaptation of the scale used in our studies was prepared by Łaguna et al. (2011) $(\alpha=0.77-0.84)$. 


\section{Big Five Inventory}

The Big Five Inventory (John \& Srivastava, 1999) was used to measure the Big Five personality traits (extraversion, agreeableness, conscientiousness, neuroticism, and openness) in Polish adaptation by Strus et al. (2014).

\section{Modified Differential Emotions Scale (mDES)}

The Modified Differential Emotions Scale (mDES) (Fredrickson, 2013; Fredrickson et al., 2003) was used. The participants indicated the frequency of their experience (over the past two weeks) on a 5-point Likert scale from 0 (not at all) to 7 (most of the time) for ten positive emotions: amusement, awe, contentment, gratitude, hope, inspiration, interest, joy, love and pride $(\alpha=0.90)$, and 10 negative emotions: anger, shame, fear, disgust, embarrassment, guilt, sadness, contempt, stress, hate $(\alpha=0.86)$.

\section{Satisfaction With Life Scale}

The Satisfaction With Life Scale (SWLS) (Diener et al.,1985) measures global cognitive judgments of satisfaction with one's life. The Polish adaptation of the scale used in our studies was prepared by Jankowski (2015). Items are rated on a 7-point Likert scale from 1 (strongly disagree) to 7 (strongly agree) with five items (e.g., "In most ways my life is close to my ideal", "If I could live my life over, I would change almost nothing") $(\alpha=0.86)$.

\section{Center for Epidemiological Studies-Depression Scale}

The Center for Epidemiological Studies-Depression Scale (CES-D) (Radloff, 1977) measures depressive symptoms. The Polish version of the scale used in our studies was prepared by Ziarko et al. (2014). The participants indicated the frequency of experienced various depressive symptoms over the past week on a 4-point Likert scale from 1 (rarely or none of the time) to 4 (often or all of the time: 5-7 days) for 20 items (e.g., "I was bothered by things that usually don't bother me", "I felt that everything I did was an effort", "I felt that people dislike me") $(\alpha=0.93)$. 


\section{Self-Compassion Scale}

The Self-Compassion Scale (Neff, 2003) measures the tendency to be compassionate towards the self. We used a shorter, 12-item Polish version of the scale in the Polish adaptation by Hołas to assess three aspects of self-compassion: self-kindness (e.g., "I try to be understanding and patient towards those aspects of my personality I don't like"), mindfulness (e.g., "When something upsets me I try to keep my emotions in balance"), and common humanity (e.g., "I try to see my failings as part of the human condition"). The participants indicated the frequency of engagement in self-compassion on a 5-point Likert scale from 1 (almost never) to 5 (almost always) for 12 items $(\alpha=0.91)$.

\section{Ego-Resilience Scale}

The Ego-Resilience Scale (Block \& Kremen, 1996) measures the tendency to adapt to continual shifts in the environment and bounce back from adversity. In this study, we used the Polish adaptation of the scale prepared by Kaczmarek (2011). Items are rated on a 4-point Likert scale from 1 (does not apply at all) to 4 (applies very strongly) (e.g., "I am regarded as a very energetic person", "My daily life is full of things that keep me interested") $(\alpha=0.81)$.

\section{Five Facet Mindfulness Questionnaire}

The Five Facet Mindfulness Questionnaire (FFMQ) (Baer et al., 2006) measures the five facets of mindfulness: observing, describing, acting with awareness, non-judgmental, and non-reactive. For our study, we used the Polish version (Radon, 2014) of the scale. The participants indicated on a 5-point scale the frequency (from 1 for (almost) never to 5 for (almost) always) of experiences listed under 39 items (e.g., "When I'm walking, I deliberately notice the sensations of my body moving", "It's hard for me to find the words to describe what I'm thinking", "I notice the smells and aromas of things") $(\alpha=0.91)$.

\section{Positive Relations with Others}

Positive Relations with Others is one of the subscales of the Psychological Well-Being Questionnaire (Ryff, 1989) and assesses the presence of satisfying interpersonal connections . The present study used a Polish version of this scale (Krok, 2009). Seven items are rated on a 7-point Likert scale from 1 (strongly disagree) 
to 7 (strongly agree) (e.g., "I often feel lonely because I have few close friends with whom to share my concerns", "I have not experienced many warm and trusting relationships with others") $(\alpha=0.82)$.

\section{Illness Symptoms Scale}

The Illness Symptoms Scale (Elliot \& Sheldon, 1998) measures 13 symptoms of poor health. The participants used a 9-point Likert scale from 0 (not at all) to 8 (very frequently) to report the frequency of each symptom (e.g., headaches, chest or heart pain) experienced over the past two weeks.

\section{Subjective Happiness Scale}

The Subjective Happiness Scale (SHS) (Lyubomirsky \& Lepper, 1999) measures the level of happiness in a broad and global sense. The participants indicated on a 7-point Likert scale the degree to which each statement applied to them, e.g., "In general, I consider myself" from 1 (not a very happy person) to 7 (a very happy person); "Compared to most of my peers, I consider myself" from 1 (less happy) to 7 (most happy); "Some people are generally very happy. They enjoy life regardless of what is going on, getting the most out of everything. To what extent does this characterization describe you?" from 1 (not a great deal) to 7 (a great deal $)(\alpha=0.79)$.

\section{Valuing Happiness Scale}

The Valuing Happiness Scale (Mauss et al., 2011) measures the tendency to value happiness to an extreme degree. This study used the Polish adaptation of the scale by Czarniecka et al. (2012). The participants indicated their agreement and disagreement on a 7-point Likert scale from 1 (strongly disagree) to 7 (strongly agree) with seven items (e.g., "To have a meaningful life, I need to feel happy most of the time", "Feeling happy is extremely important to me") $(\alpha=0.78)$.

\section{RESULTS}

To determine the internal structure of the PP-PL scale, we performed a confirmatory factor analysis (CFA; Brown, 2006) with ML estimation, using AMOS 24 
(Arbuckle, 2014). In Table 1, we present the results of the CFA for two models: Model 1, which does not contain any error covariances, and Model 2, which was created based on the modification indices and includes covariance among the error terms between items 1 and 2. For Model 1, the CFI values greater than .95 and SMR values less than .06 indicate an acceptable model fit, although the RMSEA indexes greater than .06 indicate a poor model fit (Hu \& Bentler, 1999) in all three samples. In Model 2, the CFA results show a very good fit of the model for Samples 1 and 3 and an acceptable model fit in Sample 2. In addition, all standardized factor loadings (for both models) were higher than .60, which suggests that the items loaded highly onto a single factor. Moreover, Cronbach's $\alpha$ reliability was acceptable in all three samples (Sample 1: $\alpha=.83$; Sample 2: $\alpha=.87$; and Sample 3: $\alpha=.85$ ).

\section{Table 1}

Confirmatory Factor Analysis Results

\begin{tabular}{|c|c|c|c|c|c|c|}
\hline & \multicolumn{3}{|c|}{ Model 1} & \multicolumn{3}{|c|}{ Model 2} \\
\hline & Sample 1 & Sample 2 & Sample 3 & Sample 1 & Sample 2 & Sample 3 \\
\hline \multicolumn{7}{|c|}{$\begin{array}{l}\text { Factor loadings } \\
\text { (standardized } \\
\text { estimate) }\end{array}$} \\
\hline Item 1 & .73 & .82 & .75 & .68 & .77 & .69 \\
\hline Item 2 & .71 & .84 & .76 & .66 & .80 & .70 \\
\hline Item 3 & .74 & .73 & .67 & .76 & .75 & .69 \\
\hline Item 4 & .72 & .77 & .79 & .74 & .78 & .82 \\
\hline Item 5 & .62 & .62 & .68 & .64 & .64 & .70 \\
\hline$\chi^{2}$ & 14.52 & 17.17 & 17.84 & 3.13 & 10.98 & 3.83 \\
\hline$d f$ & 5 & 5 & 5 & 4 & 4 & 4 \\
\hline$p$ & .013 & .004 & .003 & .537 & .027 & .429 \\
\hline$\chi^{2} / d f$ & 2.91 & 3.43 & 3.57 & .78 & 2.75 & .96 \\
\hline SRMR & .03 & .03 & .03 & .01 & .03 & .01 \\
\hline $\begin{array}{l}\text { RMSEA } \\
(90 \% \mathrm{CI})\end{array}$ & $\begin{array}{c}.09 \\
(.04-.14)\end{array}$ & $\begin{array}{c}.10 \\
(.05-.15)\end{array}$ & $\begin{array}{c}.11 \\
(.06-.16)\end{array}$ & $\begin{array}{c}0 \\
(0-.08)\end{array}$ & $\begin{array}{c}.08 \\
(.03-.14)\end{array}$ & $\begin{array}{c}0 \\
(0-.099)\end{array}$ \\
\hline CFI & .98 & .98 & .97 & 1.00 & .99 & 1.00 \\
\hline AIK & 34.52 & 37.17 & 37.84 & 25.13 & 32.98 & 25.83 \\
\hline
\end{tabular}

Note. SRMR = Standardized Root Mean Square Residual, RMSEA = Root Mean Square Error of Approximation, $\mathrm{CFI}=$ Comparative Fit Index, AIC = Akaike's Information Criterion.

Item descriptive statistics (means and standard deviations for the one-factor version of the scale are presented in Table 2). 
Table 2

Item Descriptive Statistics

\begin{tabular}{|c|c|c|c|c|c|c|c|}
\hline \multicolumn{2}{|c|}{ Item } & \multicolumn{2}{|c|}{$\begin{array}{l}\text { Sample 1 } \\
(n=231)\end{array}$} & \multicolumn{2}{|c|}{$\begin{array}{l}\text { Sample } 2 \\
(n=253)\end{array}$} & \multicolumn{2}{|c|}{$\begin{array}{l}\text { Sample } 3 \\
(n=226)\end{array}$} \\
\hline Polish version & English version & $M$ & $S D$ & $M$ & $S D$ & $M$ & $S D$ \\
\hline $\begin{array}{l}\text { 1. Doświadczanie } \\
\text { szczęścia w codzien- } \\
\text { nym życiu jest dla } \\
\text { mnie priorytetem }\end{array}$ & $\begin{array}{l}\text { 1. A priority for me is } \\
\text { experiencing happiness } \\
\text { in everyday life }\end{array}$ & 7.23 & 1.44 & 6.96 & 1.81 & 7.04 & 1.67 \\
\hline $\begin{array}{l}\text { 2. Poszukuję swoich } \\
\text { pozytywnych odczuć } \\
\text { i pielęgnuję je w sobie }\end{array}$ & $\begin{array}{l}\text { 2. I look for and } \\
\text { nurture my positive } \\
\text { emotions }\end{array}$ & 6.84 & 1.70 & 6.86 & 1.65 & 6.97 & 1.63 \\
\hline $\begin{array}{l}\text { 3. To, w jaki sposób } \\
\text { spędzam czas wolny od } \\
\text { pracy zależy od tego, } \\
\text { jak dużo pozytywnych } \\
\text { emocji mogę wtedy } \\
\text { doświadczyć }\end{array}$ & $\begin{array}{l}\text { 3. What I decide to do } \\
\text { with my time outside } \\
\text { of work is influenced } \\
\text { by how much I might } \\
\text { experience positive } \\
\text { emotions. }\end{array}$ & 6.77 & 1.58 & 6.79 & 1.65 & 6.91 & 1.72 \\
\hline $\begin{array}{l}\text { 4. Planuję swój dzień } \\
\text { w taki sposób, by } \\
\text { doświadczać jak naj- } \\
\text { więcej szczęścia }\end{array}$ & $\begin{array}{l}\text { 4. I structure my day } \\
\text { to maximize } \\
\text { my happiness }\end{array}$ & 5.87 & 1.82 & 5.97 & 1.71 & 5.91 & 1.83 \\
\hline $\begin{array}{l}\text { 5. Moje ważne decyzje } \\
\text { w życiu (np. wybór } \\
\text { zawodu, zakup domu) } \\
\text { zależą od tego, jak } \\
\text { dużo pozytywnych } \\
\text { odczuć mogę w związ- } \\
\text { ku z tym doświadczyć }\end{array}$ & $\begin{array}{l}\text { 5. My major decisions } \\
\text { in life (e.g. the job } \\
\text { I choose, the house } \\
\text { I buy) are influenced } \\
\text { by how much I might } \\
\text { experience positive } \\
\text { emotions }\end{array}$ & 6.50 & 1.81 & 6.62 & 1.72 & 6.52 & 1.86 \\
\hline
\end{tabular}

The results of variable correlations for all three samples are presented in Table 3. PP moderately and positively correlated with positive orientation, extraversion, positive emotions, satisfaction with life, mindfulness, and subjective happiness. We also found significant positive yet weaker correlations between PP and conscientiousness, agreeableness, and self-compassion. In Samples 2 and 3 PP correlated moderately and negatively with depressive symptoms. A weak, negative correlation was found between PP and negative emotions as well as neuroticism. The results obtained by Catalino et al. $(2014,2020)$ show very similar significant correlations of PP with personality characteristics such as agreeableness and neuroticism as well as $\mathrm{PP}$ and positive and negative emotions. 


\section{Table 3}

Descriptive Statistics of Study Variables and Correlations Between Prioritizing Positivity and Other Study Variables

\begin{tabular}{|c|c|c|c|c|c|c|c|c|c|}
\hline \multirow[b]{2}{*}{ Variable } & \multicolumn{3}{|c|}{ Sample 1} & \multicolumn{3}{|c|}{ Sample 2} & \multicolumn{3}{|c|}{ Sample 3} \\
\hline & $M$ & $S D$ & $r$ & $M$ & $S D$ & $r$ & $M$ & $S D$ & $r$ \\
\hline Prioritizing Positivity & 33.19 & 6.51 & & 33.21 & 6.92 & & 33.57 & 6.89 & \\
\hline Positive orientations & 28.38 & 3.31 & $.47 * *$ & & & & & & \\
\hline Extraversion & 3.11 & .58 & $.32 * *$ & & & & & & \\
\hline Agreeableness & 3.66 & .54 & $.18^{* *}$ & & & & & & \\
\hline Conscientiousness & 3.56 & .66 & $.24 * *$ & & & & & & \\
\hline Neuroticism & 3.04 & .80 & $-.19 * *$ & & & & & & \\
\hline Openness & 3.76 & .53 & .12 & & & & & & \\
\hline Positive Emotions & & & & 33.06 & 6.24 & $.47 * *$ & 31.80 & 7.54 & $.29 * *$ \\
\hline Negative Emotions & & & & 22.81 & 6.26 & $-.21 * *$ & 22.21 & 7.72 & .01 \\
\hline Satisfaction with Life & & & & 23.26 & 5.08 & $.39 * *$ & 22.62 & 5.82 & $.30 * *$ \\
\hline Depressive Symptoms & & & & 13.61 & 10.93 & $-.32 * *$ & 13.93 & 11.48 & $-.18^{*}$ \\
\hline Self Compassion & & & & 38.05 & 8.06 & $.14^{*}$ & & & \\
\hline Ego Resilience & & & & 40.44 & 5.86 & $.31 * *$ & & & \\
\hline Mindfulness & & & & & 17.80 & $.30 * *$ & & & \\
\hline Positive Relations & & & & 37.37 & 6.57 & $.33 * *$ & & & \\
\hline Illness Symptoms & & & & 30.83 & 15.05 & -.10 & & & \\
\hline Valuing Happiness & & & & & & & 27.86 & 7.16 & .11 \\
\hline Subjective Happiness & & & & & & & 19.22 & 5.15 & $.31 * *$ \\
\hline
\end{tabular}

$* p<.05 ; * * p<.01$.

Analysis results of $t$-test for the independent samples indicate no differences in PP levels for age and education in all three samples. We also found no differences in PP levels for gender in Samples 1 and 3. However, in Sample 2 men $(M=34.09, S D=6.01)$ reported higher levels of PP than women $(M=30.32 ; S D=8.79)$ : $t(250)=3.71, p<.001$, Cohen's $d=.50$.

\section{DISCUSSION}

The present research examined the psychometric properties of the Polish version of the Prioritizing Positivity Scale (PP-PL). Replicating some of the research done by Catalino et al. (2014), we investigated the relationship between prioritizing positivity 
and well-being. Our results show that PP-PL has good psychometric properties and is a valid and reliable instrument to measure the tendency to prioritize positive-emotion generating activities. Furthermore, the scale has satisfactory reliability and can, therefore, be used in further research. We also confirmed the one-factor structure of the scale.

Prioritizing positivity is related to several indicators of well-being, such as positive emotions and fewer depressive symptoms. The results also suggest that high levels of prioritizing positivity are associated with a broader range of psychosocial resources, i.e., mindfulness, self-compassion, positive relations with others, and ego-resilience. As in Catalino et al. (2014), our results indicate that prioritizing positivity is positively and moderately associated with valuing happiness.

It must be noted that well-being is a broad construct that includes different components. In the present study, apart from using the Satisfaction with Life Scale, which measures an individual's general and more specific judgments of overall satisfaction-the cognitive component of subjective well-being, we included a measure of Subjective Happiness. This instrument reflects a more general category of well-being and relates to one's assessment of oneself as generally happy or unhappy. However, it is not the same as judging the levels of recently experienced positive emotions and satisfaction with life (Lyubomirsky \& Lepper, 1999). In the present study, the results point to stronger correlations between prioritizing positivity and subjective happiness than with satisfaction with life. This may suggest that in our sample, the overall assessment of oneself as happy is a better indicator of the choice of activities that increase the experience of positive emotions.

As with any research, limitations need to be discussed. First, we used a crosssectional design in the studies, so interpretations of the observed associations between prioritizing positivity and indicators of well-being should be made with caution. Secondly, presented studies were also limited by the sampling methodparticipants in all studies were primarily women. In Sample 2, gender influenced the levels of PP, significantly higher levels of PP were observed in males. However, in the other two samples, such a difference did not occur. Future research should analyze the potential significance of such gender differences in levels of PP and its functional role.

The growing body of research (Catalino et al., 2017; Van Capellen et al., 2017) indicates practical applications of prioritizing positivity for overcoming barriers related to engagement in positive health behaviors and strengthening the experience of positive emotions while engaging in everyday activities. All of that contributes to the experience of greater well-being and, happiness, as such. A further longitudinal study should assess the long-term effects of prioritizing positivity and its role in well-being. This knowledge could contribute to developing more positive psycholo- 
gy interventions to increase the levels of experienced positive emotions and clinical interventions to modify beliefs that are adverse to one's well-being.

\section{CRediT Author Statement}

JAŚMINA MACHLAH (50\%): conceptualization, methodology, writing (original draft, review \& editing), formal analysis, project administration.

MARIUSZ ZIĘBA (50\%): conceptualization, methodology, investigation, formal analysis, writing (review and editing), project administration.

\section{REFERENCES}

Arbuckle, J. L. (2014). Amos (Version 23.0) [Computer Program]. IBM SPSS.

Baer, R. A., Smith, G. T., Hopkins, J., Krietemeyer, J., \& Toney, L. (2006). Using self-report assessment methods to explore facets of mindfulness. Assessment, 13, 27-45. https://doi. org/10.1177\%2F1073191105283504

Block, J., \& Kremen, A. M. (1996). IQ and ego-resiliency: Conceptual and empirical connections and separateness. Journal of Personality and Social Psychology, 70, 349-361. https://doi.org/10.1037/0022-3514.70.2.349

Brown, T. A. (2006). Confirmatory factor analysis for applied research. Guilford Press.

Caprara, G. V. (2009). Positive orientation: Turning potentials into optimal functioning. The Bulletin of the European Health Psychologist, 11(3), 46-48.

Caprara, G. V., Alessandri, G., Eisenberg, N., Kupfer, A., Steca, P., Caprara, M. G., Yamaguchi, S., Fukuzawa, A., \& Abela, J. (2012). The Positivity Scale. Psychological Assessment, 24(3), 701-712. https://doi.org/10.1037/a0026681

Catalino, L. I., Algoe, S. B., \& Fredrickson, B. L. (2014). Prioritizing positivity: An effective approach to pursuing happiness? Emotion, 14, 1155-1161. https://doi.apa.org/doi/10.1037/emo0000177

Catalino, L. I., \& Boulton, A. J. (2020). The psychometric properties of the Prioritizing Positivity Scale. Journal of Personality Assessment, 103(5), 705-715. https://doi.org/10.1080/00223891 .2020 .1828433

Catalino, L. I., Van Cappellen, P., Boulton, A., Firestine, A., \& Fredrickson, B. L. (2017). Prioritizing positivity predicts engagement in new wellness behaviors that evoke positive emotions. [Manuscript in preparation].

Cohn, M. A., Fredrickson, B. L., Brown, S. L., Mikels, J. A., \& Conway, A. M. (2009). Happiness unpacked: Positive emotions increase life satisfaction by building resilience. Emotion, 9, 361-368. https://doi.apa.org/doi/10.1037/a0015952

Czarniecka, I. D., Glińska, K. M., Wika, M. T., \& Szóstakiewicz, O. A. (2012). Paradoksalne skutki wartościowania szczęścia [Paradoxical effects of happiness valuation] [Unpublished manuscript]. Institute of Psychology, Adam Mickiewicz University, Poznań.

Datu, J. A. D., \& King, R. B. (2016). Prioritizing positivity optimizes positive emotions and life satisfaction: A three-wave longitudinal study. Personality and Individual Differences, 96, 111-114. https://doi.org/10.1016/j.paid.2016.02.069 
Diener, E., Emmons, R. A., Larsen, R. J., \& Griffin, S. (1985). The Satisfaction With Life Scale. Journal of Personality Assessment, 49, 71-75. https://doi.org/10.1207/s15327752jpa4901_13

Diener, E., Sandvik, E., \& Pavot, W. (1991). Happiness is the frequency, not the intensity, of positive versus negative affect. In F. Strack, M. Argyle, \& N. Schwarz (Eds.), Subjective well-being: An interdisciplinary perspective. Pergamon.

Elliot, A. J., \& Sheldon, K. M. (1998). Avoidance personality goals and the personality-illness relationship. Journal of Personality and Social Psychology, 75, 1282-1299. https://doi.apa.org/ doi/10.1037/0022-3514.75.5.1282

Fredrickson, B. L. (2001). The role of positive emotions in positive psychology: The broaden-and-build theory of positive emotions. American Psychologist, 56(3), 218-226. https://doi.org/10.1037/0003066X.56.3.218

Fredrickson, B. L. (2013). Positive emotions broaden and build. Advances in Experimental Social Psychology, 47, 1-53. https://doi.org/10.1016/B978-0-12-407236-7.00001-2

Fredrickson, B. L., Tugade, M. M., Waugh, C. E., \& Larkin, G. R. (2013). What good are positive emotions in crisis? A prospective study of resilience and emotions following the terrorist attacks on the United States on September 11th, 2001. Journal of Personality and Social Psychology, 84(2), 365-376. https://doi.org/10.1037/0022-3514.84.2.365

Jankowski, K. S. (2015). Is the shift in chronotype associated with an alteration in well-being? Biological Rhythm Research, 46(2), 237-248. https://doi.org/10.1080/09291016.2014.985000

John, O. P., \& Srivastava, S. (1999). The Big Five Trait taxonomy: History, measurement, and theoretical perspectives. In L. A. Pervin \& O. P. John (Eds.), Handbook of personality: Theory and research (2nd ed., pp. 102-138). Guilford Press.

Kaczmarek, Ł. (2011). Skala Sprężystości Psychicznej - polska adaptacja Ego Resiliency Scale [Polish adaptation of the Ego Resiliency Scale]. Czasopismo Psychologiczne, 17, 263-265.

Krok, D. (2009). Religijność a jakość życia w perspektywie mediatorów psychospołecznych. Redakcja Wydawnictw WT UO.

Lyubomirsky, S., \& Lepper, H. S. (1999). A measure of subjective happiness: Preliminary reliability and construct validation. Social Indicators Research, 46(2), 137-155. https://doi. org/10.1023/A:1006824100041

Lyubomirsky, S., King, L., \& Diener, E. (2005). The benefits of frequent positive affect: Does happiness lead to success? Psychological Bulletin, 131(6), 803-855.

Łaguna, M., Oleś, P., \& Filipiuk, D. (2011). Orientacja pozytywna i jej pomiar: Polska adaptacja skali orientacji pozytywnej [Positive orientation and its measure: Polish adaptation of the Positivity Scale]. Studia Psychologiczne, 49(4), 47-54. https://doi.org/10.2478/v10167-010-0035-7

Mauss, I. B., Tamir, M., Anderson, C. L., \& Savino, N. S. (2011). Can seeking happiness make people unhappy? Paradoxical effects of valuing happiness. Emotion, 11, 807-815. https://doi.org/10.1037/ a0022010

Neff, K. D. (2003). The development and validation of a scale to measure self-compassion. Self \& Identity, 2(3), 223. https://doi.org/10.1080/15298860309027

Passmore, H.-A., Howell, A. J., \& Holder, M. D. (2018). Positioning implicit theories of well-being within a positivity framework. Journal of Happiness Studies, 19(8), 2445-2463. https://doi. org/10.1007/s10902-017-9934-2

Radoń, S. (2014). Pięciowymiarowy kwestionariusz uważności: Polska adaptacja [Five Facet Mindfulness Questionnaire: Polish adaptation]. Annals of Psychology, 17(4), 711-735.

Radloff, L. S. (1977). The CES-D Scale: A self-report depression scale for research in the general population. Applied Psychological Measurement, 1(3), 385-401. https://doi. org/10.1177/014662167700100306 
Russo-Netzer, P. (2019). Prioritizing meaning as a pathway to meaning in life and well-being. Journal of Happiness Studies, 20(6), 1863-1891. https://doi.org/10.1007/s10902-018-0031-y

Russo-Netzer, P., \& Littman-Ovadia, H. (2019). "Something to Live for": Experiences, resources, and personal strengths in late adulthood. Frontiers in Psychology, 10, 2452. https://doi.org/10.3389/ fpsyg.2019.02452

Ryff, C. D. (1989). Happiness is everything, or is it? Explorations on the meaning of psychological well-being. Journal of Personality \& Social Psychology, 57(6), 1069-1081. https://doi. org/10.1037/0022-3514.57.6.1069

Schütz, E., Sailer, U., Al Nima, A., Rosenberg, P., Andersson Arntén, A. C., Archer, T., \& Garcia, D. (2013). The affective profiles in the USA: Happiness, depression, life satisfaction, and happiness-increasing strategies. PeerJ, 1:e156. https://doi.org/10.7717/peerj.156

Strus, W., Cieciuch, J., \& Rowiński, T. (2014b). Polska adaptacja kwestionariusza IPIP-BFM-50 do pomiaru pięciu cech osobowości w ujęciu leksykalnym [Polish adaptation of IPIP-BFM-50 for measuring five personality traits using a lexical approach]. Roczniki Psychologiczne, 17(2), 327-346.

Van Cappellen, P., Rice, E. L., Catalino, L. I., \& Fredrickson, B. L. (2018). Positive affective processes underlie positive health behaviour change. Psychology \& Health, 33(1), 77-97. https://doi.org/ $10.1080 / 08870446.2017 .1320798$

Ziarko, M., Kaczmarek, Ł., \& Haładziński, P. (2014). Polish version of Centre for Epidemiological Studies Depression Scale (CES-D): Results of a preliminary study on the psychometric properties of the scale. Current Issues in Personality Psychology, 1(1), 51-61. https://doi.org/10.5114/ cipp.2013.40637 